\title{
Pelatihan dan Pendampingan UMKM di Desa Gajahrejo dalam Pembuatan Desain Kemasan Inovatif Oleh-Oleh Khas Malang Untuk Meningkatkan Daya Saing Produk
}

\author{
Dediek Tri Kurniawan ${ }^{1 *}$, Inanda Shinta Anugrahani ${ }^{2}$, Arum Prasasti $^{3}$, Raisa Fitri ${ }^{4}$ \\ ${ }^{1,3,4}$ Departemen Manajemen, Universitas Negeri Malang \\ ${ }^{2}$ Departemen Akutansi, Universitas Negeri Malang \\ J1 Semarang No 9 Malang \\ *Penulis Korespondensi. Email: dediek.kurniawan.fe@um.ac.id
}

\begin{abstract}
ABSTRAK
Salah satu masalah yang dihadapi oleh UMKM di Malang adalah menciptakan kemasan yang menarik khususnya produk makanan dan oleh-oleh khas Malang. Padahal peran kemasan sangat penting karena menciptakan kesan pertama bahkan sebelum produk dikonsumsi. Kemasan telah mendukung penciptaan nilai tambah bagi sebuah produk dari segi bentuk, warna, hingga grafisnya. Kemasan juga berfungsi dalam membangun indentitas sebuah produk. Indentitas yang tidak konsisten dapat menyebabkan konsumen kesulitan dalam mengenal produk tersebut. Program pengabdian ini akan melakukan proses redesign kemasan dari produk oleh-oleh khas di Malang. Program pengabdian ini akan dilakukan di Desa Gajahrejo terletak di Kecamatan Gedangan di Kabupaten Malang. Program pengabdian ini akan fokus bagaimana mendampingi pelaku UMKM di Desa Gajahrejo untuk mengembangkan desain kemasan yang diharapkan mampu meningkatkan tingkat daya saing produk tersebut. Program pendampigan pada pelaku UMKM di Desa Gajahrejo yang terdiri dari: persepsi dan harapan UMKM terhadap kemasan yang ingin dihasilkan untuk produk dengan pengisian data. Luaran yang diharapkan dalam program ini adalah desain baru dari produk peserta pelatihan. Proses pemetaan produk-produk Desa Gajahrejo menemukan bahwa produk-produk yang dihasilkan disana memiliki kualitas yang baik dan potensial untuk dikembangkan. Pendampingan pembuatan kemasan produk Desa Gajahrejo sementara hanya fokus pada dua produk yaitu kopi dan nugget kulit pisang yang diyakini memiliki potensi untuk diterima di pasar. "Gajahrejo" merupakan merek (brand) yang akan digunakan untuk produk-produk Desa Gajahrejo. Meskipun hanya dua produk yang dikembangkan, pengemasan dengan berbagai volume dilakukan untuk produk-produk bervariasi
\end{abstract}

Kata Kunci: UMKM, Desain Kemasan, added value, Malang

\begin{abstract}
One of SMEs' problems in Malang is creating attractive packaging, especially for food and souvenirs product on Malang. However, the packaging's role is vital because it creates the first impression even before it is consumed. Packaging has supported creating added value for a product in terms of shape, color, and graphics. Packaging also functions in building the identity of a product. An inconsistent identity can cause consumers to have difficulty recognizing the product. This community service program will redesign the packaging of typical souvenir products in Malang. This service program will be carried out in Gajahrejo, Gedangan District, Malang. This service program will focus on assisting SMEs in Gajahrejo Village to develop packaging designs that are expected to increase the level of competitiveness of these products. Assistance program for SME actors in Gajahrejo consists of SMEs' perceptions and expectations on the packaging they want to produce for products by filling in data. The expected output in this program is a new design of the training participants' products. The process of mapping Gajahrejo Village products found that the products produced there were of good quality and had the potential to be developed. Assistance in making packaging for Gajahrejo Village products only focuses on two products, namely coffee, and banana peel nuggets, which are believed to have the potential to be accepted in the market. "Gajahrejo" is a brand that will be used for Gajahrejo Village products. Although only two products were developed, packaging of various volumes was carried out for various products.
\end{abstract}

Keywords: SME, packaging design, added value, Malang 


\section{PENDAHULUAN}

Malang tidak hanya dikenal dengan potensi wisatanya, Malang juga dikenal menghasilkan berbagai produk berkualitas mulai dari produk makanan dan minuman, produk seni dan kerajinan, produk pertanian, dan sebagaianya. Sebagian besar produkproduk tersebut dihasilkan melalui industri skala rumah tangga dari Usaha Menengah Kecil Mikro (UMKM) yang berada di Malang. Keberadaan mereka juga berkotribusi bagi perekonomian di Malang. Menurut data dinas koperasi dan UMKM tercatat, terdapat sebanyak 70 ribu UMKM di Malang pada 2017. Meskipun beberapa UMKM telah berhasil mengembangkan produknya, tidak sedikit UMKM yang menghadapi berbagai kesulitan dalam mengembangkan produknya.

Salah satu masalah yang dihadapi oleh UMKM di Malang adalah menciptakan kemasan yang menarik khususnya produk makanan dan oleh-oleh khas Malang. Padahal peran kemasan sangat penting karena menciptakan kesan pertama bahkan sebelum produk dikonsumsi. Pada awalnya kemasan (package) adalah satu komponen penting digunakan untuk mengemas suatu benda/produk agar tetap dalam kondisi yang baik (Setiawan \& Oemar, 2015). Pada perkembangan kemasan berfungsi dari sebuah pelindung dari sebuah produk tapi lebih dari itu. Desain kemasan justru kiat menguatkan persepsi sebuah kualitas produk. Tampilan dan estetika kemasan justru menjadi sangat penting dalam membangun brand sebuah produk. Setiadi (2005) menjelaskan fungsi kemasan sebagai informasi, sebagai pelindung produk, dan branding/merek (Permadi, Susatyo, \& Pujotomo, 2017). Suatu desain kemasan yang buruk dapat menimbulkan citra jelek terhadap sebuah produk dan sebaliknya kemasan yang baik dapat menarik minat pembeli terhadap sebuah produk (Theophany, Bramantya, \& Sutanto, 2014). Dari pentingnya masalah kemasan sebuah produk, program pengabdian ini akan melakukan proses redesign kemasan dari produk oleh-oleh khas di Malang. Target yang akan dibidik dalam program pengabdian ini adalah UMKM di Malang yang memproduksi produk khas Malang. Dengan keterbatasan tenaga dan waktu, program ini akan dilakukan di satu desa saja yang dianggap memeliki produk yang berkualitas namun membutuhkan penyempurnaan terhadap desain kemasan yang telah ada. Program ini akan fokus bagaimana mendampingi pelaku UMKM setempat untuk membuat kemasan yang menarik di pandang.

Program pengabdian ini akan dilakukan di Desa Gajahrejo terletak di Kecamatan Gedangan di Kabupaten Malang. Desa yang memiliki luas sekitar 1.171.864 Ha memiliki penduduk yang mayoritas berprofesi dalam bidang pertanian, jasa/perdagangan dan industri. Desa Gajahrejo memiliki berbatasan langsung dengan Samudra Hindia sehingga memiliki kawasan pantai yang berpotensi dikembangkan sebagai kawasan wisata. Terdapat tiga pantai yang bisa dikembangkan seperti pantai Bajulmati, pantai Ungapan, dan pantai Batu Bengkung. Meskipun demikian, masalah penggangguran masih menjadi tugas berat yang dihadapi di Desa Gajahrejo. Menurut website desa gajahrejo, setidaknya tercatat sekitar 938 orang yang menyandang pengangguran untuk penduduk usia 15-55 tahun. Angka itu cukup besar melihat jumlah penduduk Desa Gajahrejo sekitar 3938 orang.

Program pengabdian ini akan fokus bagaimana mendampingi pelaku UMKM di Desa Gajahrejo untuk mengembangkan desain kemasan yang diharapkan mampu meningkatkan tingkat daya saing produk tersebut. UMKM yang dibidik adalah pelaku usaha di bidang produk makanan dan oleh-oleh khas Malang. Kegiatan ini ditargetkan menghasilkan desain kemasan yang bisa langsung digunakan pelaku UMKM disana dan siap didistribusikan di pasar. Kegiatan ini juga akan memberhatikan elemen-elemen penting dalam proses desain kemasan. Proses desain Menurut Nillson \& Ostrom (2005) dalam Permadi, Susatyo, \& Pujotomo (2017) 
menjelaskan bahwa kemasan terdiri dari tiga dimensi yaitu: desain grafis, struktur desain, dan informasi produk. Pada desain grafis terdiri dari empat sub dimensi yaitu: nama merek, warna, tipografi, dan gambar. Struktur terdiri dari tiga sub dimensi yaitu bentuk, ukuran, dan material. Kemasan dari sebuah produk harus memenuhi beberapa faktor yaitu: pengamanan, ekonomi, pendistribusian, komunikasi, ergonomi, estetika dan identitas (Theophany et al., 2014).

\section{METODE}

Proses pengabdian yang dilakukan akan fokus pada "Pelatihan dan Pendampingan UMKM di Desa Gajahrejo dalam Pembuatan Desain Kemasan Inovatif Oleh-Oleh Khas Malang untuk Meningkatkan Daya Saing Produk". Hasil luaran akhir dari program ini adalah pembuatan desain kemasan berdasarkan kebutuhan dari pelaku Usaha Mikro Kecil Menengah (UMKM). Adapun rencanan progam adalah sebagai berikut:

\section{Tahap Persiapan}

Tahap persiapan terdiri dari penyusunan proposal dan rencana program/kegiatan yang dilakukan. Tahap ini meliputi identifikasi kebutuhan dalam pelaksanaan pengabdian masyarakat serta upaya koordinasi dengan perangkat desa. Pada tahap ini juga dilakukan perencaaan sasaran dari program pengabdian dan penentuan indikator keberhasilan program.

\section{Tahap pelaksanaan}

Pada tahap ini dimulai pendataan dan penggalian informasi dari kondisi lapangan di Desa Gajahrejo. Informasi yang didapat digunakan untuk merancang penyesuaian program yang diharapkan lebih efektif pada pelaksanaan program kegiatan. Kegiatan kunjungan dan observasi awal menjadi starting point dalam kegiatan ini. Sharing session digunakan untuk menggali informasi dari perangkat Desa Gajahrejo dan pelaku UMKM disana. Pada saat bersamaan, pendataan produk unggulan Desa Gajahrejo juga dilakukan karena keterbatasan waktu dan biaya tidak memungkinkan untuk mengakomodasi seluruh produk yang ada. Program kegiatan yang dilakukan diupayakan sesuai dengan program dan strategi pembangunan di Desa Gajahrejo. Setelah data dan infromasi didapat, pelaksanaan program akan dilakukan sebanyak dua kali pendampingan. Program pendampingan pada pelaku UMKM di Desa Gajahrejo yang terdiri dari: pendataan persepsi dan harapan UMKM terhadap kemasan yang ingin dihasilkan untuk produk dengan pengisian data. Perserta juga diminta menyetorkan informasi seputar produk dari: nama produk, sertifikasi produk, komposisi bahan produk, deskripsi produk, data UMKM (nama, alamat, kontak), harga, dan tempat penjualan). Dari hasil data yang dikumpulkan tim akan melakukan desain dari produk tersebut. Desain tersebut akan diupayakan memenuhi keingan dan persepsi pemilik produk. Hal ini menuntut proses pendampingan tidak cukup hanya satu kali saja. Namun, proses pendampingan akan dilakukan minimal sebanyak tiga kali.

3. TahapEvaluasi Program

Tahap evaluasi terdiri dari proses kajian permasalahan-permasalahan yang muncul selama proses pendampingan pembuatan kemasan Desa Gajahrejo. Evaluasi diharapkan mampu memberikan perbaikan dari pelaksanaan ke depan.

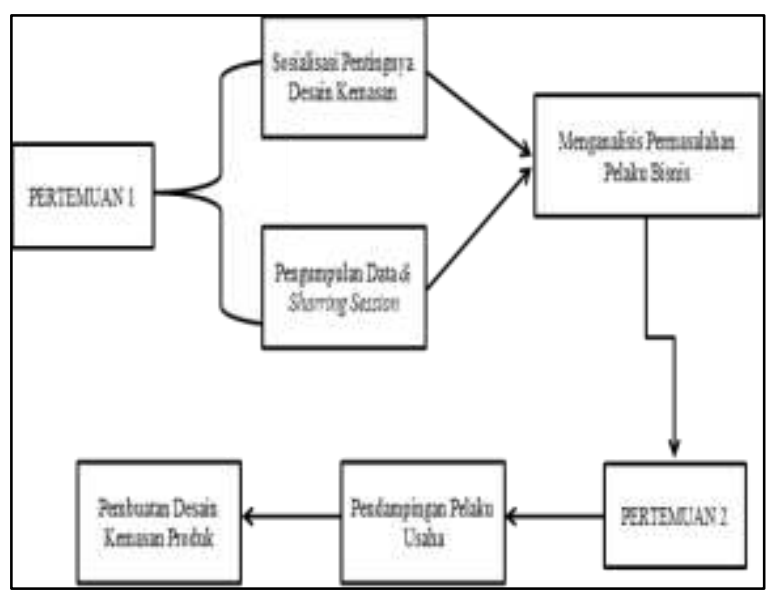

Gambar 1. Desain Kegiatan Pendampingan Pembuatan Kemasan Produk Desa Gajahrejo 


\section{PEMBAHASAN}

\section{Tahap Persiapan}

Setelah melakukan sharing session dengan perangkat Desa Gajahrejo, berbagai data dan informasi telah didapat untuk perancangan program pendampingan pembuatan desain kemasan produk Desa Gajahrejo.

\section{Pemetaan Produk Unggulan}

Program awal yang dijalankan dalam hal ini adalah kunjungan dalam rangka menggali informasi dan data sebanyak-banyaknya dengan pihak terkait seperti Kepala Desa Gajahrejo dan beberapa masyarakat setempat. Pada awal kegiatan didapat pemetaan produk-produk yang menjadi fokus dalam pembuatan desain kemasan. Semua produk itu merupakan produk unggulan dan memiliki daya saing di Desa Gajahrejo. Dari hasil wawancara dan diskusi dari pihak terkait di Desa Gajahrejo, terdapat beberapa produk potensial yang menjadi target pengembangan desain.

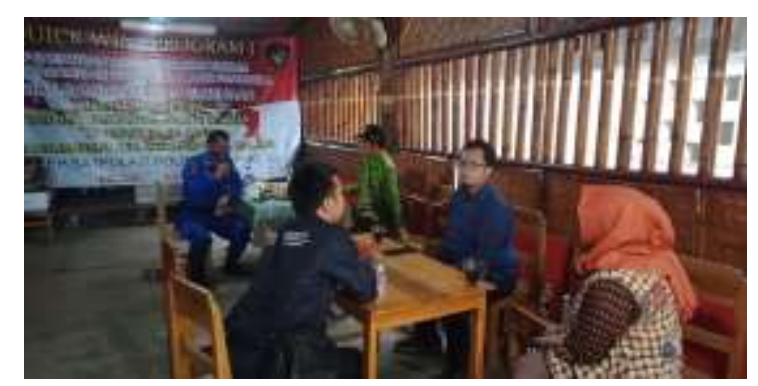

Gambar 2. Kunjungan ke Desa Gajahrejo

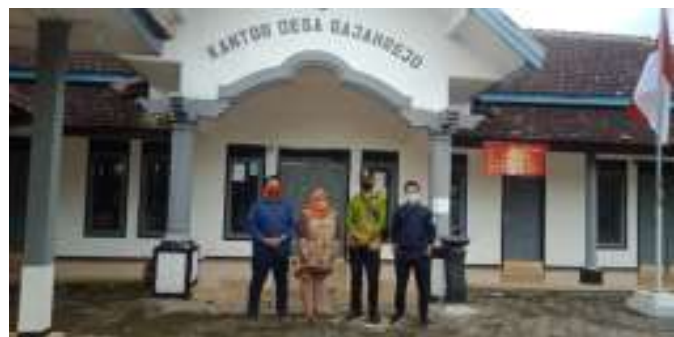

Gambar 3. Kunjungan ke Desa Gajahrejo

\section{Tahap Pelaksanaan Program}

Sosialisasi dan pemberian pengetahuan dan pemahaman mengenai pentingnya desain kemasan bagi kesuksesan pemasaran suatu produk. Sosialisasi ini akan diberikan oleh pemateri dari Universitas Negeri Malang. Dalam kesempatan pertama, tim akan melakukan pendataan peserta pelatihan yang meliputi nama, usia, dan jenis produk lokal yang dihasilkan. Pendataan awal ini diperlukan sebagai database tim pelaksana. Tim akan membantu peserta dalam menganalisis permasalahan pelaku bisnis.

Tabel 1. Pelatihan Pertemuan Pertama

\begin{tabular}{|l|l|l|l|}
\hline \multicolumn{1}{|c|}{ Tipe Pelatihan } & \multicolumn{1}{c|}{ Metode Pelatihan } & \multicolumn{1}{c|}{ Konten } & \multicolumn{1}{c|}{ Peserta } \\
\hline $\begin{array}{l}\text { Metode-metode presentasi } \\
\text { (Presentasi Methods) }\end{array}$ & $\begin{array}{l}\text { Pengajaran } \\
\text { dilaksanakan di ruang } \\
\text { Metode pelatihan dimana orang-orang } \\
\text { tertutup, berbantuan dilatih merupakan penerima } \\
\text { informasi pasif }\end{array}$ & $\begin{array}{l}\text { Pentingnya } \\
\text { slide presentasi dan } \\
\text { video }\end{array}$ & $\begin{array}{l}\text { UMKM di } \\
\text { Kesa } \\
\text { Kesanan } \\
\text { Gajahrejo }\end{array}$ \\
\hline $\begin{array}{l}\text { Sharring Session (Diskusi, Tanya } \\
\text { jawab) }\end{array}$ & $\begin{array}{l}\text { Diskusi (tanya jawab) } \\
\text { dilaksanakan pada } \\
\text { Metode dimana peserta saring } \\
\text { melakukan interaksi tanya jawab. }\end{array}$ & $\begin{array}{l}\text { Permasalahan } \\
\text { Pelaku Bisnis }\end{array}$ & $\begin{array}{l}\text { UMKM di } \\
\text { Desa } \\
\text { Gajahrejo }\end{array}$ \\
\hline
\end{tabular}


Dalam pertemuan ini, tim pelaksana juga mengumpulkan informasi terkait produk yang dihasilkan oleh peserta. Berikut adalah format angket yang akan dibagikan pada peserta pelatihan.

\section{Tahap Perancangan Desain Kemasan}

Program pelatihan kedua adalah pelatihan dalam pembuatan desain kemasan produk oleh UMKM di Desa Gajahrejo. Model pelatihan akan fokus pada pendampingan mengenai pembuatan desain kemasan produk. Output luaran yang ingin dicapai pada kegiatan ini adalah desain kemasan produk yang dihasilkan oleh pelaku bisnis. Perancangan desain kemasan akan dilakukan sebelum pertemuan kedua agar pertemuan lebih efektif dan efisien. Analisis VIEW (visibility, information, emotional appeal, workability) digunakan untuk menganalisa data-data yang ada pada kemasan terkait fungsi pada kemasan dan membangun identitas dan citra lewat pembangunan visual yang dpata menarik perhatian konsumen (visibility), keberadaan informasi-informasi seputar publik (information), kemampunan kemasan untuk menimbulkan perasaan tertentu (emotional appeal), dan segi fungsional dari kemasan (workability).

a. Brand

Nama merek (brand) yang digunakan adalah "Gajahrejo". Nama "Gajahrejo" diambil dari nama Desa Gajahrejo. Nama "Gajahrejo" dianggap kata yang mudah diingat dan sangat familiar.

\section{b. Warna}

Pemilihan warna dalam kemasan menggunakan warna-warna mencolok sepetri merah biru, hijau. Pemilihan warna yang kontras ini dimaksudkan mampu menarik perhatian.

c. Bahan

Mengingat beberapa produk yang dikembangkan Desa Gajahrejo, bahan yang digunakan akan bervariasi mulai dari standing pouch, kemasan plastik, dan toples kaca. Adapaun rincian dari bahan yang digunakan adalah:

Tabel 2. Pemilihan Bahan Kemasan

\begin{tabular}{|l|l|l|}
\hline \multicolumn{1}{|c|}{ Produk } & Desain Kemasan & \multicolumn{1}{c|}{ Bahan } \\
\hline \multirow{4}{*}{ Kopi Bubuk } & Standing pouch & $\begin{array}{l}\text { Standing Pouch Ecopack dengan ukuran 13x } \\
\text { 21cm. Kertas Lapis Alumunium Foil 150Z. } \\
\text { Kapasitas isi mencapai 150gr kopi, dilengkapi } \\
\text { zipper }\end{array}$ \\
\cline { 3 - 4 } & Toples kaca & $\begin{array}{l}\text { Toples Kaca Botol dengan tinggi 15 cm diameter } \\
7 \mathrm{~cm} \text {. Kemasan ini tahan Panas. Kapasitas isi } \\
\text { mencapai 500ml/500gr }\end{array}$ \\
\hline \multirow{2}{*}{$\begin{array}{l}\text { Nugget Kulit } \\
\text { Pisang }\end{array}$} & Kemasan plastik & $\begin{array}{l}\text { Vakumpack dengan ukuran 30x30cm. Kemasan } \\
\text { ini berbentuk plastik kemasan Vacuum Frozen }\end{array}$ \\
& & $\begin{array}{l}\text { Food. Vacuum Sealer Mesin Seal Plastik } \\
\text { Freshpack Kemasan Makanan Beku }\end{array}$ \\
\hline
\end{tabular}

d. Logo

Sebelumnya, produk-produk Desa Gajahrejo masih belum memiliki logo yang akan digunakan sebagai identitas. Hal ini mendorong pembuatan logo untuk produk Desa Gajahrejo. Penggalian konsep logo dimulai dengan menentukan tema sebagai acuan dalam perencanaan desain kemasan. Tema yang akan digunakan atau brand image yang ingin ditampilkan adalah "desa" dan "tradisional". Konsep logo yang dibuat dibuat sesederhana mungkin agar mudah dipahami oleh konsumen. Logo yang disesuaikan dengan permintaan dari perangkat desa. Dari penggalian informasi oleh, ilustrasi logo 
yang dibuat adalah "seorang ibu". Filosofi gambar ibu mewakili arti "ketulusan" dimana produk gajahrejo memberikan yang terbaik dengan ketulusan. Sesuai dengan tema, penampilan ibu dalam logo memiliki penampilan ibu-ibu khas perdesaan dan memiliki kesan tradisional

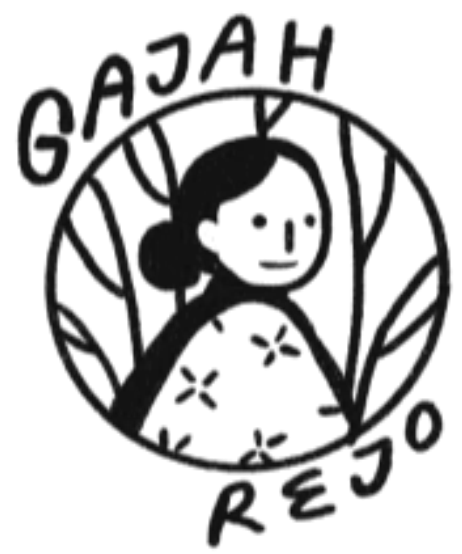

Gambar 4. Konsep Logo Gajahrejo

e. Ilustrasi (gambar)

Dalam memperkuat branding, ilustrasi akan memperkuat karakter dan suasana perdesaan. Untuk kemasan kopi, karakter ibu dengan pakaian tradisional lengkap teko khas tradisional menjadi upaya penguatan pesan produk kopi. Ilustrasi yang akan digunakan adalah berupa ilustrasi drawing atau gambaran tangan pada komputer dengan bantuan tenaga ahli pada bidang desain visual.

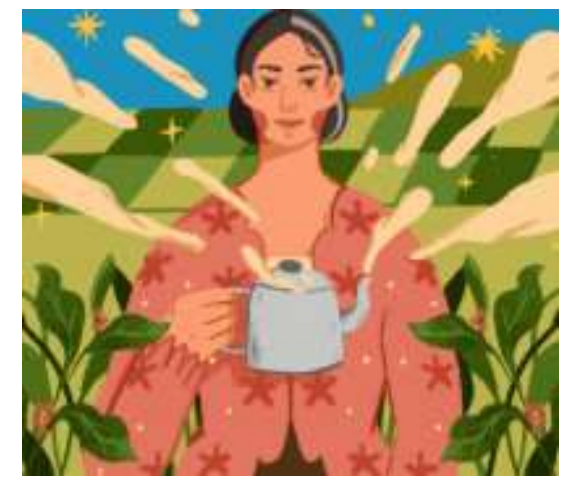

Gambar 5. Ilustrasi untuk Kemasan Produk Kopi

Ilustrasi untuk produk nugget kulit pisang juga masih memperlihatkan kesan "desa" dan tradisional". Hal itu dapat dilihat dari ilustrasi barang-brang yang digunakan.

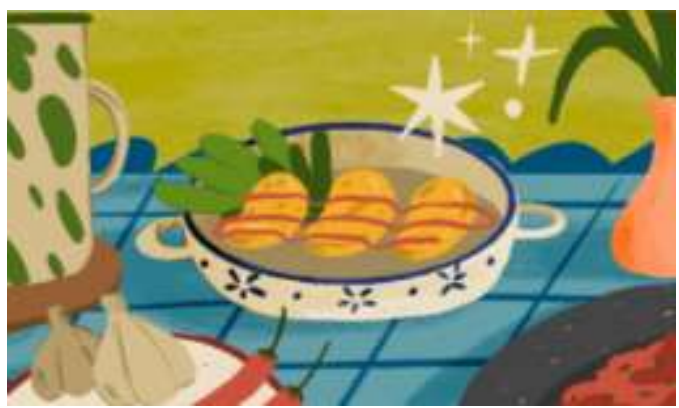

Gambar 6. Ilustrasi untuk Kemasan Produk Nugget Kulit Pisang

f. Tipografi

Jenis font yang digunakan adalah tipe sans serif untuk deskripsi yang digunakan sedangkan font pada logo yang digunakan adalah vagoda dari situs www.freepik.com. Pemilihan jenis font tersebut didasarkan pada kepentingan aspek visual.

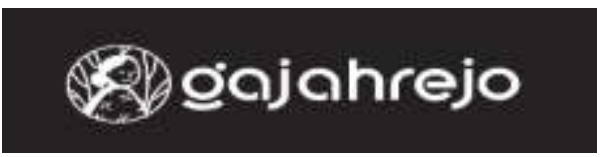

\section{Gambar 7. Modifikasi Font untuk Logo}

Dari hasil pengembangan kemasan pada produk-produk Desa Gajahrejo, dihasilkan variasi produk berdasarkan ukuran dan jenis kemasan yang digunakan. Pada gambar dibawah ini didapat dilihat variasi produk dihasilkan dari penggunaan jenis dan warna kemasan yang digunakan.

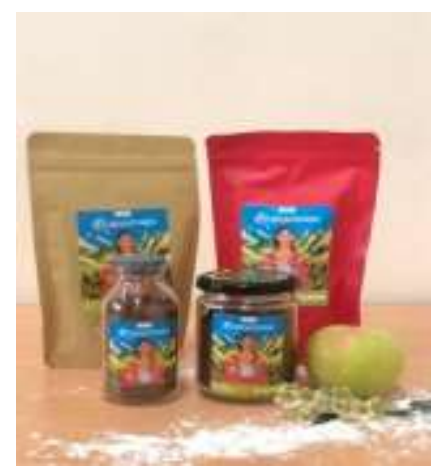

Gambar 8. Desain Akhir Kemasan Produk Gajahrejo 
untuk dikembangkan. Dalam melaksanakan sebuah pendampingan pembuatan kemasan produk Desa Gajahrejo. Pembuatan kemasan tidak sebatas memilih kemasan yang baik tetapi juga melakukn desain mulai dari pembuatan logo, desain, ilustrasi, sampai pada pembuatan foto konten untuk promosi produk dari Desa Gajahrejo. Pendampingan pembuatan kemasan produk Desa Gajahrejo sementara hanya fokus pada dua produk yaitu kopi dan nugget kulit pisang yang diyakini memiliki potensi untuk diterima di pasar. "Gajahrejo" merupakan merek (brand) yang akan digunakan untuk produk-produk Desa Gajahrejo. Meskipun hanya dua produk yang dikembangkan, pengemasan dengan berbagai volume dilakukan untuk produk-produk bervariasi.

\section{UCAPAN TERIMAKASIH}

Penulis menyampaikan terimakasih

Gambar 10. Kemasan Produk Gajahrejo jenis botol

\section{KESIMPULAN DAN SARAN}

Di tengah persaingan bisnis yang kian kompetitif, fungsi kemasan kian berkembang tidak hanya sebagai pelindung sebuah produk. Fungsi kemasan juga berperan penting dalam mempengaruhi konsumen dalam memilih sebuah produk. Apalagi, produk yang ditawarkan membanjiri pasar. Kemasan telah mendukung penciptaan nilai tambah bagi sebuah produk dari segi bentuk, warna, hingga grafisnya. Kemasan juga berfungsi dalam membangun indentitas sebuah produk. Indentitas yang tidak konsisten dapat menyebabkan konsumen kesulitan dalam mengenal produk tersebut.

Proses pemetaan produk-produk Desa Gajahrejo menemukan bahwa produk-produk yang dihasilkan disana memiliki kualitas yang baik dan potensial da Universitas Negeri Malang yang mendukung penuh dalam program pengabdian ini sehingga dapat terlaksana dengan baik. Penulis juga menyampaikan terima kasih kepada Kepala Desa dan seluruh masyaraket Desa Gajahrejo Kecamatan Gedangan, Kabupaten Malang yang telah membantu dalam pelaksanaan pengabdian ini baik secara langsung maupun tidak langsung dan semoga program ini bermanfaat bagi masyarakat setempat

\section{DAFTAR PUSTAKA}

Permadi, D. T., Susatyo, N. W. P., \& Pujotomo, D. (2017). Perancangan desain kemasan makanan ringan olahan pada UMKM center Jawa Tengah dengan metode Kansei Engineering. Industrial Engineering Online Journal, 6(1), 1-9.

Setiawan, R. D., \& Oemar, E. A. B. (2015). Pengembangan desain kemasan 
kripik singkong UD Aji Jaya Makmur. Jurnal Pendidikan Seni Rupa, 3(3), 183189.

Theophany, H., Bramantya, B., \& Sutanto, R. P. (2014). Studi visual perubahan desain kemasan sosis "Bernardi " tahun 2009-2013. Jurnal Desain Komunikasi Viasual Adiwarna, 1-13 